\title{
UI KADAR LOGAM BERAT PADA SAMPEL AIR DAN KERANG DI MUARA CENGKARENG DRAIN
}

Imam Santoso, Maryam Jameelah, Arif Subiyandono, Epong Utami, Hambali Ahmad, Tia Wadiastuti

Departement of Chemistry, Faculty of Mathematics and Natural Sciences Universitas Negeri Jakarta, Jl. Pemuda No.10Rawamangun 13220, Jakarta Indonesia

\begin{abstract}
Abstrak
Muara Cengkareng Drain merupakan salah satu muara yang termasuk ke dalam 13 muara yang masuk ke area Teluk Jakarta. Sepanjang aliran sungai Cengkareng Drain banyak terdapat pabrik dan perumahan yang dapat menyebabkan pencemaran pada badan air. Pencemaran yang paling mengkhawatirkan adalah pencemaran oleh logam berat. Tujuan dari penelitian ini adalah untuk mengetahui kadar logam berat $\mathrm{Hg}, \mathrm{Pb}, \mathrm{Cd} \mathrm{pada}$ sampel air laut dan kerang di Muara Cengkareng Drain hingga lokasi pertambakan kerang. Hasil menunjukkan kadar $\mathrm{Hg}$ pada ketiga lokasi sampling berkisar antara 0.001-0.002 mg/l. Kadar Hg dan $\mathrm{Pb}$ pada sampel kerang hijau adalah sebesar 0.12 dan $0.4 \mathrm{mg} / \mathrm{kg}$. Kadar Pb tidak terdeteksi pada sampel air dan kadar Cd tidak terdeteksi pada sampel air dan kerang.
\end{abstract}

Kata Kunci :

Uji Kadar Logam, Berat, sampel air, kerang.muara Cengkareng drain

\begin{abstract}
Cengkareng Drain Estuary is one of the estuary that is included in the 13 estuaries that enter the area of the Jakarta Bay. Cengkareng Drain along the river there are many factories and housing that can cause pollution in water bodies. The most alarming pollution is pollution by heavy metals. The purpose of this study was to determine the levels of heavy metals $\mathrm{Hg}, \mathrm{Pb}, \mathrm{Cd}$ in samples of seawater and shellfish in the estuary until Cengkareng Drain clams aquaculture site. The results showed $\mathrm{Hg}$ levels in all three sampling locations ranged from 0001-0002 mg / I. Levels of $\mathrm{Hg}$ and $\mathrm{Pb}$ in mussels sampled were at 0.12 and $0.4 \mathrm{mg} / \mathrm{kg}$. Levels of $\mathrm{Pb}$ was not detected in water samples and the levels of $\mathrm{Cd}$ was not detected in water samples and shellfish
\end{abstract}

Keywords

Test levels of heavy metals, water samples, shellfish, Cengkareng Drain Estu

\section{Pendahuluan}

Pencemaran lingkungan atau polusi adalah masuknya atau dimasukkannya makhluk hidup, zat energi dan atau komponen lain kedalam lingkungan, atau berubahnya tatanan lingkungan oleh kegiatan manusia atau proses alam sehingga kualitas lingkungan turun sampai tingkatan tertentu yang menyebabkan lingkungan menjadi kurang atau tidak dapat berfungsi lagi sesuai peruntukannya (Undang-Undang Pengelolaan Lingkungan Hidup No. 4 Tahun 1982). Pencemaran ini dapat dihasilkan dari aktivitas manusia, baik pada proses industri ataupun dihasilkan dari rumah tangga. Hasil buangan tersebut dapat masuk ke badan air sehingga menyebabkan perubahan pada perairan, baik sungai, danau, air tanah, hingga air laut atau istilah ini disebut sebagai pencemaran air.
Berkembangnya industrialisasi dan semakin padatnya perumahan penduduk, utamanya di sepanjang aliran sungai dapat menyebabkan menurunna kualitas lingkungan, apalgi jika tidak diiringindengan upaya penanggulangannya. Limbah yang seringkali dikhawatirkan adalah limbah buangan dari pabrik atau perindustrian yang banyak menggunakan bahan berbahaya. Salah satu bahan berbahaya tersebut adalah logam berat. Logam berat ini dapat bersifat korosif, sifat korosif limbah industri utamanya berasal dari pipa-pipa besar industri setempat yang dialirkan ke sungai atau tempat pembuangan tanpa diolah terlebih dahulu [3]. Logam berat yang bersifat toksik bagi manusia diantaranya adalah logam $\mathrm{Hg}, \mathrm{Pb}$, dan $\mathrm{Cd}$. Keberadaan logam berat ini pada suatu perairan dapat terakumulasi dalam rantai makanan biota 
perairan. Hal ini dapat membahayakan bagi konsumen yang berada pada tingkat akhir dari rantai makanan.

Salah satu biota perairan yang diamati berkaitan dengan sifatnya sebagai feeding filter, adalah kerang. Sebagai makanan, kerang dapat menjadi sumber protein. Namun demikian, hal ini dapat bersifat racun jika kerang yang dikonsumsi mengandung sejumlah logam berat. Jika kerang yang mengandung logam berat dikonsumsi oleh manusia, hal ini dapat berakibat racun karena akumulasi logam dalam tubuh manusia. Berdasarkan latar belakang tersebut maka penting dilakukan suatu penelitian untuk mengetahui kadar logam berat pada sampel air dan sampel kerang di Muara Cengkareng Drain.

Tabel 1. Hasil pengukuran kadar logam berat pada ketiga lokasi sampling

\begin{tabular}{|c|c|c|c|}
\hline \multirow{2}{*}{ stasiun } & \multicolumn{3}{|c|}{ Kadar logam berat $(\mathrm{mg} / \mathrm{l})$} \\
\cline { 2 - 4 } & $\mathrm{Hg}$ & $\mathrm{Pb}$ & $\mathrm{Cd}$ \\
\hline 1 & 0.001667 & $<0.023$ & $<0.003$ \\
\hline 2 & 0.002 & $<0.023$ & $<0.003$ \\
\hline 3 & 0.001667 & $<0.023$ & $<0.003$ \\
\hline
\end{tabular}

\section{Metode Penelitian}

Metode yang digunakan dalam penelitian ini adalah metode deskriptif. Teknik pengambilan sampel yang akan digunakan dalam penelitian ini adalah purposive sampling atau pengambilan sampel berdasarkan pada tujuan pengambilan sampel. Pengambilan sampel air dilakukan di tiga titik, yaitu muara Cengkareng Drain (lokasi 1), lokasi 2 diantara Muara Cengkareng Drain dengan pertambakan kerang, dan pertambakan kerang (lokasi 3). Dari masing-masing lokasi dilakukan pengambilan sampel air berdasarkan kedalaman, yaitu permukaan, kedalaman, dan dasar perairan. Pengambilan sampel kerang diambil sebanyak tiga sampel yang didapatkan dari nelayan yang baru saja mengambil kerang di lokasi pertambakan kerang. Pengambilan sampel air dilakukan satu kali pada bulan Agustus (musim kemarau). Pengamatan diulang sebanyak satu kali, dengan sampel air berasal dari permukaan, kedalaman, dan dasar perairan. Sampel kerang diperoleh dari nelayan setempat.

Prosedur kerja dalam penelitian ini, dibagi menjadi beberapa prosedur utama, diantaranya: pengambilan sampel, pengukuran parameter fisik, persiapan pengujian sampel, dan pengujian sampel. Parameter fisik yang diukur diantaranya pengukuran $\mathrm{pH}$ air, pengukuran suhu air, warna air, kekeruhan air dan ketransparanan air, arus air. Pengukuran parameter fisik dilakukan di setiap lokasi titik sampel, masingmasing pengukuran dilakukan dengan ulangan sebanyak tiga kali.

\section{Hasil dan Pembahasan}

Pengujian kadar logam berat dilakukan dengan menggunakan alat spektrofotometer serapan atom (SSA). Berikut ini adalah tabel hasil pengujian kadar logam berat untuk parameter merkuri setelah dilakukan pengujian. Rerata hasil pengujian pada masing-masing stasiun terdapat pada tabel 1 , dan hasil pengukuran logam merkuri $(\mathrm{Hg})$ terdapat pada tabel 2 .

Tabel 2. Hasil pengukuran kadar logam merkuri pada sampel air $(\mathrm{mg} / \mathrm{l})$

\begin{tabular}{|c|c|c|}
\hline stasiun & jumlah & rerata \\
\hline 1 & 0.005 & 0.001667 \\
\hline 2 & 0.006 & 0.002 \\
\hline 3 & 0.005 & 0.001667 \\
\hline
\end{tabular}

Kadar merkuri yang terdapat pada muara Cengkareng Drain dengan lokasi lainnya, menunjukkan tidak terdapat perberbedaan secara signifikan. Berdasarkan pada PP RI No. 20 tahun 1990, mengacu kepada daftar kriteria kualitas air golongan D, yaitu peruntukan yang tidak digunakan untuk 
Tabel 3. Hasil pengukuran kadar logam pada kerang hijau

\begin{tabular}{|l|l|c|c|}
\hline \multirow{2}{*}{ jenis sampel } & \multicolumn{3}{|c|}{ Kadar logam berat yang diujikan } \\
& \multicolumn{3}{|c|}{$\mathrm{mg} / \mathrm{kg})$} \\
\cline { 2 - 4 } & $\mathrm{Hg}$ & $\mathrm{Pb}$ & $\mathrm{Cd}$ \\
\hline kerang hijau & 0.12 & 0.40 & tidak terdeteksi \\
\hline
\end{tabular}

keperluan golongan $A, B$, dan C, tetapi masih memenuhi persyaratan untuk kehidupan biota air, dimana kadar $\mathrm{Hg}$ yang diperbolehkan adalah 0.005. dengan menggunakan uji-t untuk mengetahui apakah terdapat perbedaaan antara hasil pengujian kadar merkuri pada ketiga lokasi pengambilan sampel dengan standaryang ditetapkan, diketahui bahwa tidak terdapat perbedaaan antara kadar logam berat pada lokasi sampling dengan standard peraturan pemerintah. Dengan kata lain, hasil pengujian $\mathrm{Hg}$ pada ketiga lokasi sampling dinyatakan masih berada pada taraf yang diperbolehkan.

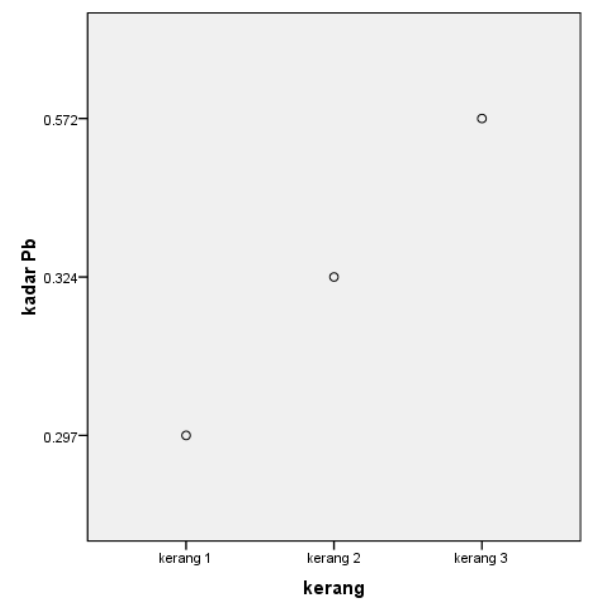

Gambar 1. Grafik konsentrasi timbal pada beberapa stasiun pengamatan

Hal ini tak berarti bahwa perairan tersebut bebas dari cemaran logam berat. Hal yang diperhatikan lebih mendalam adalah efek yang ditimbulkan dari keberadaan logam berat ini terhadap biota laut yang nantinya akan dikonsumsi oleh manusia. Hal ini yang dikhawatirkan lebih jauh, terutama mengenai efek toksik dari logam berat tersebut terhadap konsumen makanan laut. Salah satu hasil laut

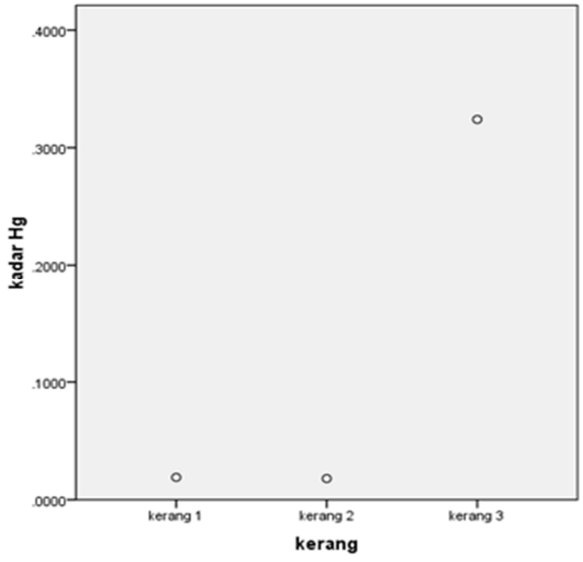

Gambar 2. Sebaran konsentrasi logam merkuri dalam sampel kerang hijau

yang menjadi pusat di Muara Angke adalah kerang hijau. Berdasarkan hasil pengujian pada sampel kerang hijau yang didapatkan langsung dari nelayan kerang hijau, dengan parameter yang sama, didapatkan hasil seperti pada tabel 3.

Kerang hijau (Perna viridis) termasuk ke dalam kelas bivalvia atau pelecypoda. Biota laut jenis ini dapat terhambat kelangsungan hidupnya jika terdapat pencemaran pada habitatnya. Berdasarkan hasil pengukuran pada ketiga parameter logam, logam $\mathrm{Hg}$ dan $\mathrm{Pb}$ yang terdeteksi secara rinci digambarkan dalam gambar 1 dan 2 .

Berdasarkan pada Standard Nasional Indonesia (SNI) 7387; tahun 2009[5.], diketahui bahwa kadar maksimum logam merkuri dan timbal yang diperbolehkan adalah sebesar $0.5 \mathrm{mg} / \mathrm{kg}$ untuk logam merkuri dan 1 $\mathrm{mg} / \mathrm{kg}$ untuk logam timbal. Kadar kedua jenis logam masih berada pada batas aman yang diperbolehkan.

Logam berat yang tak terurai oleh tubuh Hasil penelitian sebelumnya oleh Winarno $d k k$ (2009) menyatakan bahwa pemasakan kerang hijau mampu mengurangi kadar merkuri dalam daging kerang dengan kisaran 17,92 \% $44,82 \%$. Hal yang perlu diperhatikan adalah, sifat logam berat sehingga masuknya sejumlah logam berat ke dalam tubuh dalam kadar minim pun akan menimbulkan bahaya dalam 
jangka waktu tertentu, apalagi jika dikonsumsi secara rutin.

Logam berat merkuri, kadmium, dan timbal dapat menimbulkan efek toksik bagi tubuh makhluk hidup. Toksisitas masingmasing unsur pada manusia akan dijelaskan secara lebih terperinci.

Logam merkuri bersifat toksik terhadap manusia pada tiga bentuk, yaitu merkuri elemen (merkuri murni), bentuk garam inorganik dan bentuk mental, sakit kepala, dan hipersalivasi. Tremor pada otot merupakan gejala awal dari toksisitas $\mathrm{Hg}$, walaupun berat ataupun ringannya toksisitas ini bergantung pada dietorganik per harinya, Unsur merkuri dapat menyebabkan pengaruh toksik karena terjadinya proses presipitasi protein, sehingga menghambat aktivitas enzim dan bertindak sebagai bahan yang korosif. Logam ini dapat menyebabkan gangguan saraf sensorik, gangguan saraf motorik, gangguan lama mengkonsumsi, dan umur penderita [2].

Logam kadmium, jika terdapat di dalam makanan sehingga masuk ke dalam pencernaan manusia dapat menyebabkan keracunan, diabsorpsi dalam ginjal, hati, dan sebagian lainnya akan dibuang keluar melalui saluran pencernaan $[2,7]$.

Logam timbal dapat ditemukan dalam bentuk senyawa inorganik dan organik. Semua bentuk $\mathrm{Pb}$ bersifat toksik pada manusia. Walaupun pengaruh toksisitas akut jarang ditemui, tetapi pengaruh kronis paling sering ditemukan.

Beberapa organ yang dipengaruhi oleh logam ini adalah; menghambat pembentukan hemoglobin, gangguan ensefalopati, dan gejala gangguan saraf perifer. Selain efek tersebut, timbal juga mengakibatkan kolik, peningkatan permeabilitas pembuluh darah, kematian janin, dan gangguan fungsi tiroid, gejala epilepsy, kerusakan otak besar, dan delirium $[2,7]$.

Sementara itu hasil pengukuran parameter lainnya pada sampel perairan, antara lain meliputi; pengukuran $\mathrm{OD}, \mathrm{COD}$, $\mathrm{BOD}$, kekeruhan, kecerahan, $\mathrm{pH}$, arus air, suhu air, dan pengamatan terhadap permukaan air. Pengukuran kecerahan, $\mathrm{pH}$, suhu, arus air, dan pengamatan terhadap muka air dilakukan secara langsung, sementara pengujian lainnya dilakukan di laboratorium.

\section{Kesimpulan}

Berdasarkan hasil yang didapatkan dari hasil pengujian di laboratorium, dapat ditarik kesimpulan bahwa Kadar Hg pada ketiga lokasi masih berada pada taraf yang diperbolehkan.

\section{Saran}

Sementara itu saran bagi pemerintah dan para pengambil kebijakan antara lain adalah dilakukan suatu upaya pengendalian kadar logam berat atau remediasi sehingga tidak menimbulkan bahaya bagi biota laut.

\section{Daftar Pustaka}

[1] Afiati, Restu N. 2009. Analisis Kandungan Toksin PSP (Paraltic Shelfish Poisoning) dan Logam Berat Pada Kerang Hijau di Perairan Teluk Jakarta. Tesis. Universitas Diponegoro. Semarang.

[2] Darmono. 2008. Lingkungan Hidup dan Pencemaran. UI-Press. Jakarta.

[3] Departemen Kelautan dan Perikanan. 2004. Memanfaatkan Kekayaan Laut Milik Bersama : Mendukung Peran Indonesia dalam ATSEF. Diunduh dari http://www.undp.or.id/factsheets/Indonesia/fs_eu_atsef.pdf. Pada 13 April 2010 pukul 20.30 WIB. 
[4] Rumanta, M., A. Latief., U. Rahayu., A. Ratnaningsih.,G. Nurdin. 2008. Konsentrasi Timbal (Pb) pada Perairan di Sekitar Teluk Jakarta. Jurnal Matematika, Sains, dan Teknologi, Vol. 9 No. 1 : 31-36.

[5] SNI 7387. 2009. Batas Maksimum Cemaran Logam Berat dalam Pangan. Badan Standardisasi RI.

[6] Wattayahron, G. 1998. Nutrient cycling in estuarine. paper presented at project on research and its application to management of the mangrove of Asia and the pacific, Ranong. Thailand.

[7] Widowati, W., A. Sastiono., R. J. Rumampuk. 2008. EFEK TOKSIK LOGAM Pencegahan dan Penanggulangan Pencemaran. Penerbit Andi Yogyakarta. Yogyakarta.

[8] Winarno, E. K., W. Andayani., A. Sumartono. 2009. Metil Merkuri dalam Kerang Hijau (Mytilus viridis L.) dari Pasar Pelelangan Ikan Muara Angke Sebelum dan Setelah Pemasakan. Indo J. Chem Vol.9 No. 1: 77-83. 